\title{
أسلوب التعليل في سورة البقرة (دراسة نحوية تحليلية)
}

\author{
Abdul Wahab Naf'an \\ Universitas Islam Negeri Sunan Ampel Surabaya \\ rwnria@gmail.com \\ DOI: http://dx.doi.org/10.18326/lisania.v2i1.80-101
}

\begin{abstract}
This study aims to exploratory and analytical study expressions to explain the reasons or causes of something (at-ta'lîl) in the Qur'an of surah al-Baqarah. The approach used is inductive (istiqra'iy), which is the conclusion or the theory formulation (kaedah) taken after the research of all or some elements. The results of this study reveal that there are two ta'lils, which are with letters and with ism. Letter lâm is the master letter in revealing the most reasons or causes in the surah al-Baqarah which is then followed thereafter by the letters bâ', in sababiyah, hattâ, min, 'an, fî, inna,' alâ and idz. While in the form of ism, it shapes as maf'ul liajlih.
\end{abstract}

Keywords: : Ta'lîl, Sûrah al-Baqarah, Nahwu

\begin{abstract}
Abstrak
Penelitian ini bertujuan untuk mengkaji secara eksploratif dan analitis tentang ungkapan untuk menyampaiakan alasan atau sebab terjadinya sesuatu (at-ta'lîl) yang terdapat di dalam al-Qur’an Surat Al-Baqarah. Pendekatan yang digunakan yaitu dengan cara induktif (istiqra'iy), yaitu kesimpulan atau rumusan teori (kaedah) yang diambil setelah dilakukan penelitian atas semua atau sebagan elemen. Hasil dari penelitian ini mengungkapkan bahwa ada dua ta'lil, yaitu dengan huruf dan dengan ism. Huruf lâm adalah huruf induk dalam mengungkap alasan atau sebab yang terbanyak dalam QS. A-Baqarah yang kemudian diikuti setelahnya dengan huruf bâ', in sababiyah, hattâ, min, 'an, fî, inna, 'alâ dan idz. Sedangkan yang berupa ism berbentuk maf'ul liajlih.
\end{abstract}

Kata Kunci: Ta'lîl, Surat Al-Baqarah, Nahwu 


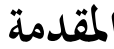

القرآن هو كتاب الله عز وجل الذى يتضمن كلماته إلى خاتم رسله وأنبيائه مُحَّة عليه الصلاة والسّالام. وللقرآن خصائص كثيرة، منها الإعجاز . ووجوه الإعجاز في القرآن متنوعة وعديدة، فكل شيئ منه لا نظير له، فهو باهر في ألفاظه وأسلوبه، في تأليفِه

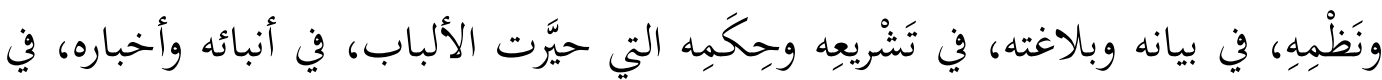
تاريخه وحفظه، وفي عُلومه التى لا تنقطع ولا تَفف عند غاية. وانطلاقا مما سبق، بذل العلماء والدارسون جهودهم في كل عصر ومصر لفهم معانى القرآن درسا وبكثا واستنتاجا. فللفقهاء والأصوليين فيه أهداف، وهم إليها طريق ومنهج. وللفلاسفة والمتكلمين فيه أهداف، وإليها طريق ومنهج، وللغويين فيه أهداف، ولهم إليها شرعة ووسيلة. ولغير هؤلاء من طلاب العلم والدرس أهداف ومناهج.

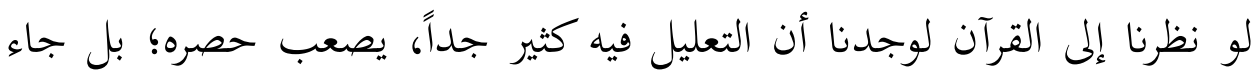
التعليل في القرآن بألفاظ هي من أصرح الألفاظ الدالة عليه. بحث الدارسون الظواهر بهريه

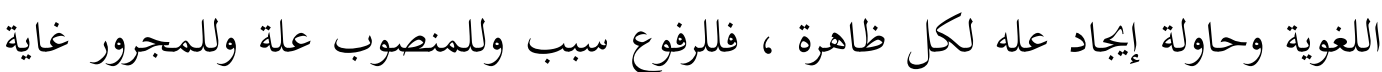
وللمجزوم هدف. غير أن العرب لم تعلل كل ما قالته إنما تصور النحاة أن العرب إنما

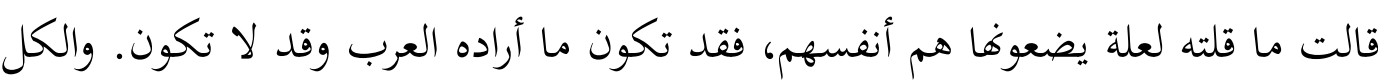
أن يعلل بما يراه علة، وبذلك تختلف العلل باختلاف واضعها وبحسب تفسيره لما يراه، إذ إذهان تتعدد الأحكام وتكثر الأراء.

وهذا البحث اعتمد على كتب اللغة والنحو والتفسير وعلوم القرآن قديمها وحديثها لدراسة أسلوب التعليل في القرآن الكريم خاصة في سورة البقرة محاولاً الإحاطة

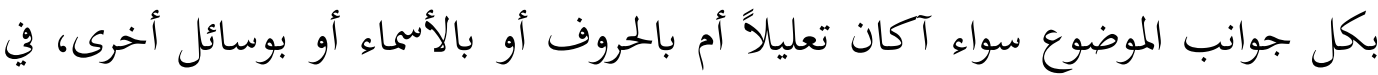
جهد علمي جديد يمثل إضافة في الدراسات النحوية والقرآنية.

\section{منهجية البحث}

هـا البحث هو من ضمن البحث النوعي، والبحث النوعي كما قال مايكل

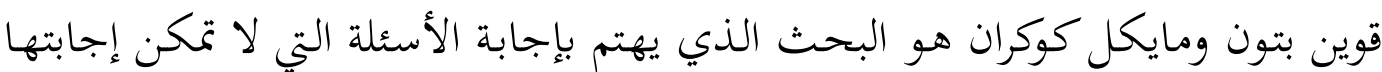


بالبيانات الكمية. والمدخل الذي يسير عليه الباحث هو المدخل الاستقرائي. والبحث

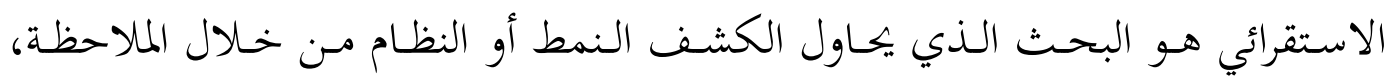
وتطوير البيانات والنظريات لهذا المنهج مسن خلال سلسلة من التحليل. والاستقراء هو

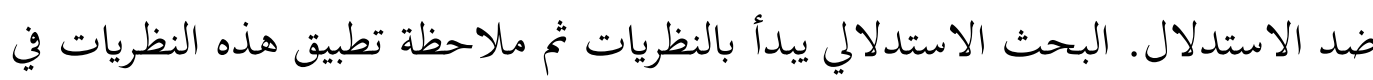

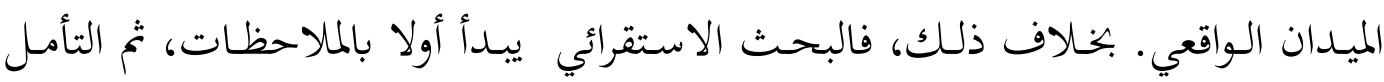
والتفكير للوصول فيما بعد إلى النمط والنظريات (عاقل يورناي: م . . ب). هذا المدخل

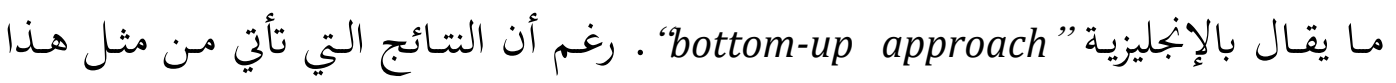
البحث قد يكون غير معين إلى درجة ما.

تكون مصادر بياناها الأولية كتابات تتعلق بموضوع البحث. وهنات وهناك مصادر أو مراجع أساسية وهناك أيضا مراجع ثانوية. ويكون المرجع الأساسي هي أسلوب التعليل

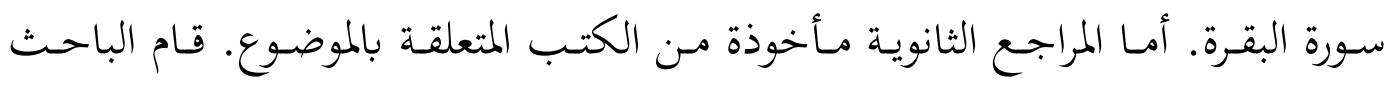

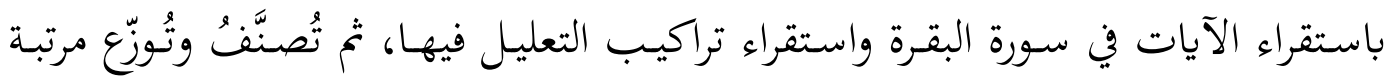
على ترتيب الآيات في هذه السورة، ثم تتم دراسته بالنتيجة.

\section{تعريف التعليل والعلة عند النحويين}

التعليل لغة مصدر علّل فهو سقي بعد سقي، وجني الثمرة مرة بعد أخرى، وتعلل

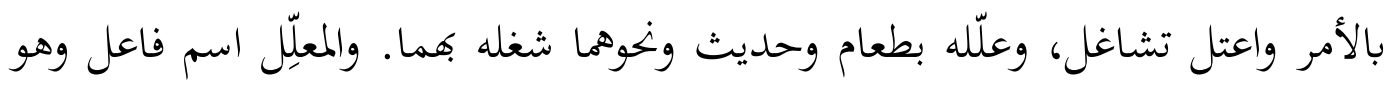

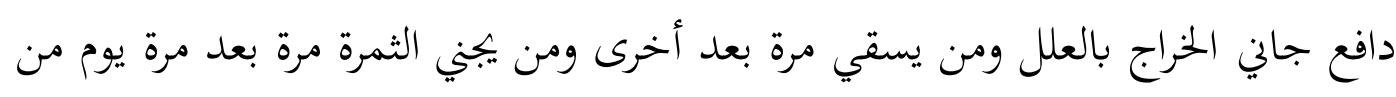

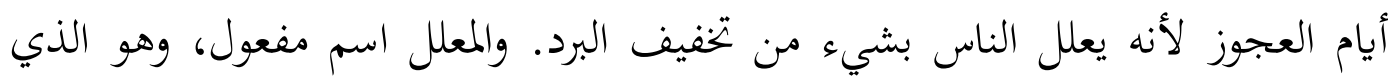

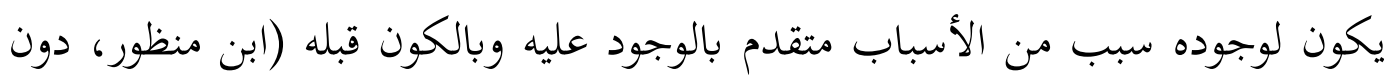
سنة: ( ) (

ويصلح تعريف بعض المحدثين للعلة النحوية أن يكون تعريفا للتعليل النحوي،

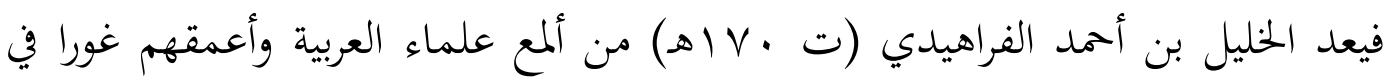

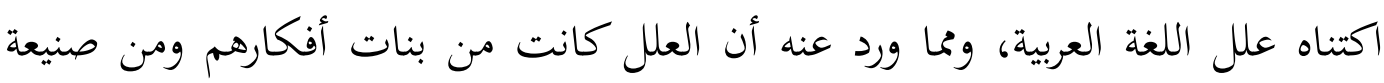
كلامهم. فقد ذكر الزجاجي (ت Vrrrه) أن الخنليل بن أحمد رحمه الله سئل عن العلل 
التي يعتل بها في النحو، فقيل له: "عن العرب أخذها أم اخترعتها من نفسك؟" فقال: "إن العرب نطقت على سجيتها وطباعها وعرفت مواقع كلامها، وقام في عقولها علله،

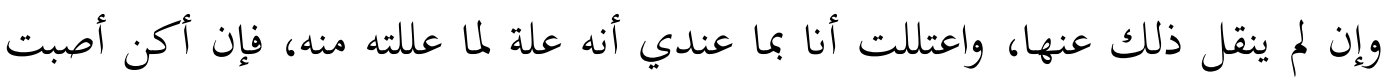
العلة فهو الذي التمست وإن تكن هناك علة له، فمثلي في ذلك مثل رجل حكيم دخل

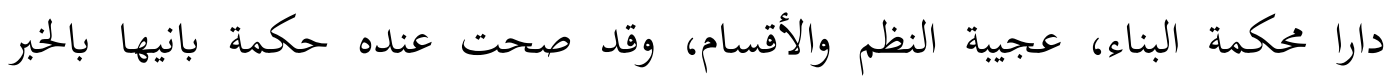

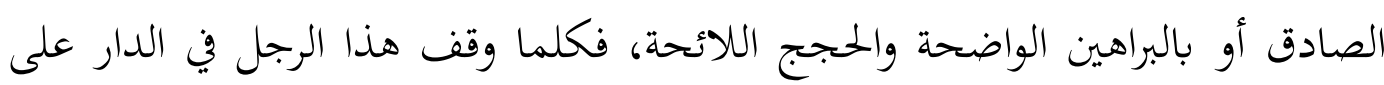
شيء منها"، قال: "إنما فعل هذا هكذا لعلة كذا وكذا، وبسبب كذا وكذا، وسنحت له له وحظرت بباله محتملة لذلك، فجائز أن يكون الحكيم الباني للدار فعل ذلك للعلة التي ذكرها هذا الذي دخل الدار، وجائز أن يكون فعله لغير تلك العلة، إلا أن ذلك مما ذكره هذا الرجل محتمل أن يكون علة لذلك، فإن سنح لغيري علة لما عللته من النحو هو أليق

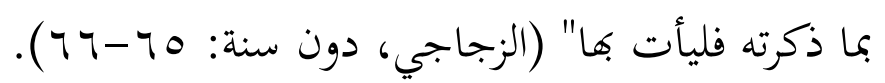

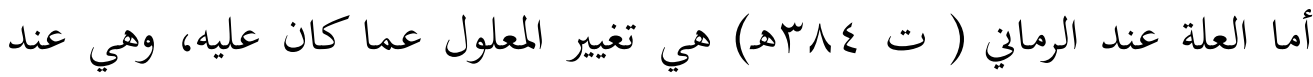
الجرجاني ما يتوقف عليه وجود الشيء ويكون خارجا مؤثرا فيه، مما دفع بعض الباحثين

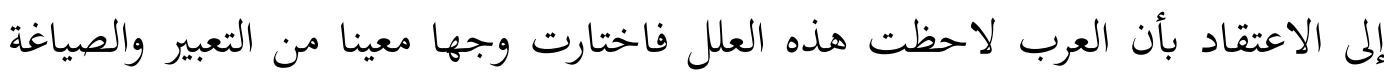
في كلامها، فهي عند د. مازن المبارك الوصف الذي يكون مظنة وجه الحكمة في اتخاذ

وبناء على أن العلة هي الجامع بين المقيس (الفرع) والمقيس عليه (الأصل)، عرفهـا د. علي أبو المكارم بأها السبب الذي تحقق في المقيس عليه فأوجب له حكما لها وتحقق في المقيس أيضا فألحق به فأخذ حكمه، غير أن العلة ليست كالسبب على ما يراه

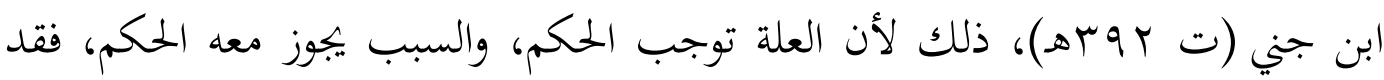
يرد على السبب مانع يؤدي إلى تحلف المسبب عنه. وبهذا يظهر أن ما كان موجبا

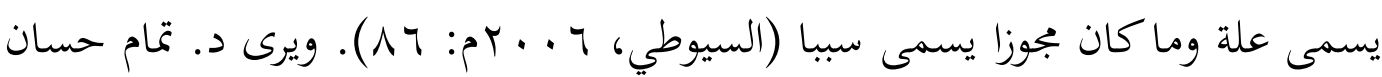

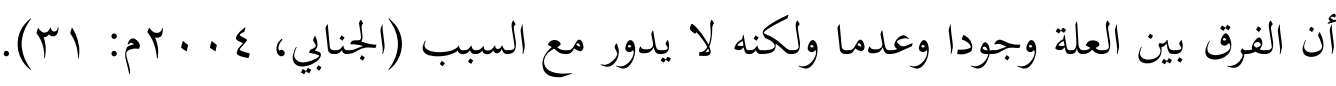




\section{أنواع العلة النحوية}

تنقسم العلة النحوية إلى ثلاثة قسام، وهي كما يلى:

العلة التعليمية: هذه العلة في جوهرها تفسير للواقع اللغوي إذ ترصدها الدراسة الوصفية للظواهر اللغوية، فتعيين العلاقات التركيبية للصيغ والمفردات في الجمل والأساليب وتتضح الوظائف النحوية. والذي حدا بالنحاة للأخذ بهذه العلة رغبتهم في تبسيط القواعد النحوية فبها يتوصل إلى كلام العرب. ومن هذا النوع من العلل قولنا:

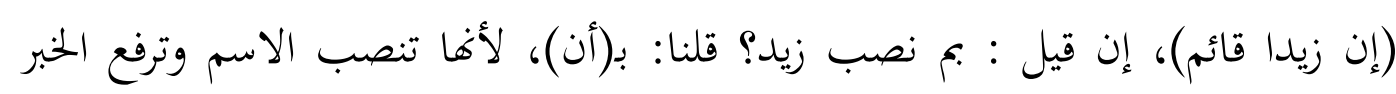
وهكذا سمعت عن العرب.

العلة القياسية: وهذه تحاول أن تربط بين الظواهر المختلفة بملاحظة ما بينها من

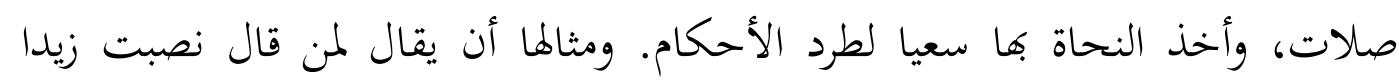

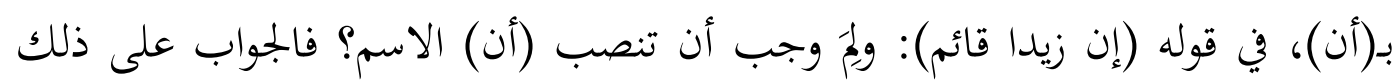

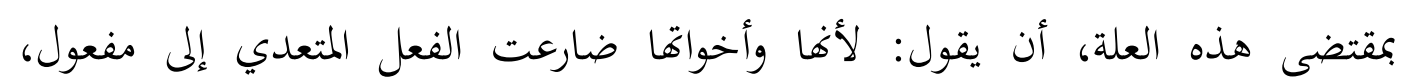
فحملت عليه فأعملت لما ضارعته فهي تشبه من الأفعال ما قدم مفعوله على فاعله.

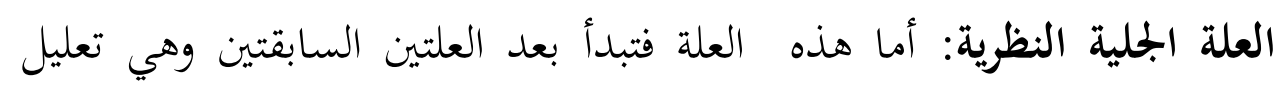

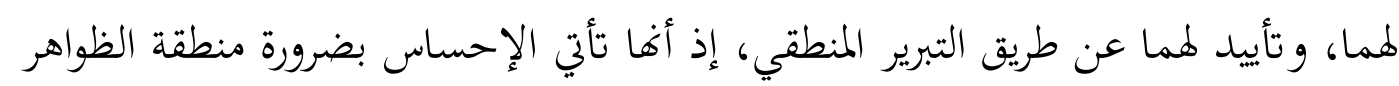

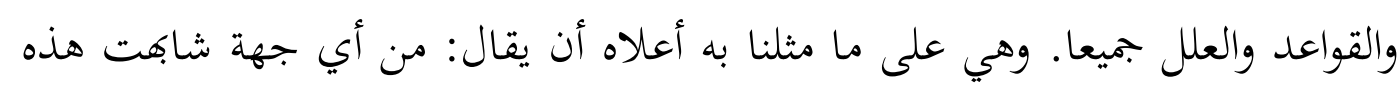

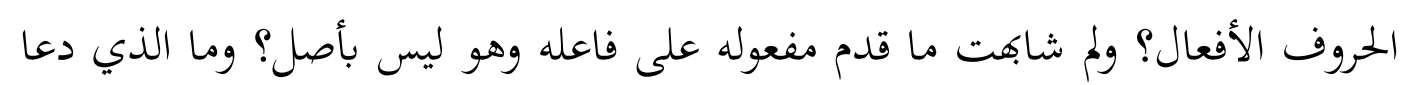
إلى إلحاقها بالفرع دون الأصل؟ الخ، فالجواب الذي يعتل به عن أي من هذه المسائل هو

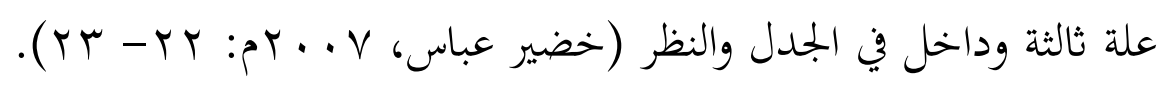

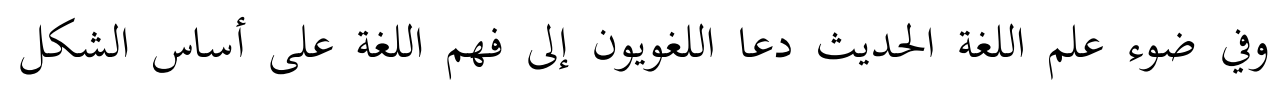

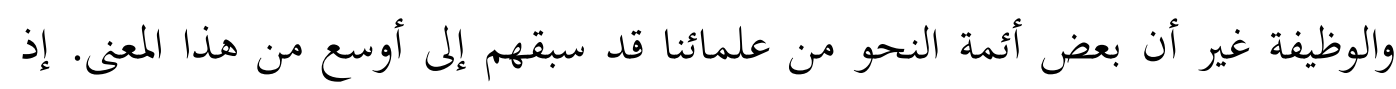

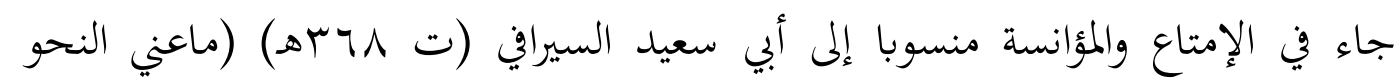

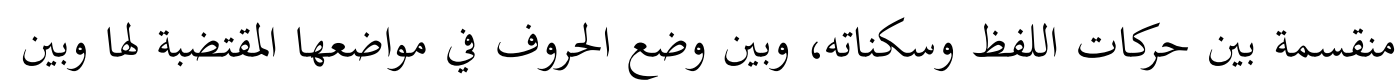

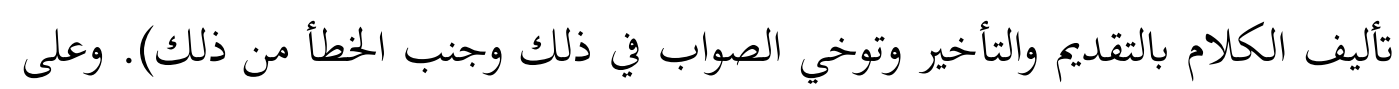


رأس هؤلاء الأئمة عبد القاهر الجرجاني (ت V Vـه) فقد ربط بين نظم الكلام وبلاغته ومعاني النحو ربطا وثيقا، وألح على هذه الفكرة في دلائل الإعجاز إلحاحا متواليا.

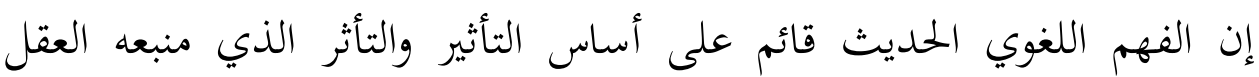
والمنطق، أما الفهم القائم على علاقات الكلمات في الجمل ووظائفها والدلالة عليها شكليا فمنبعه الوصف وأساسه عرف اللغة. والفهم القائم على معرفة العلاقة بين

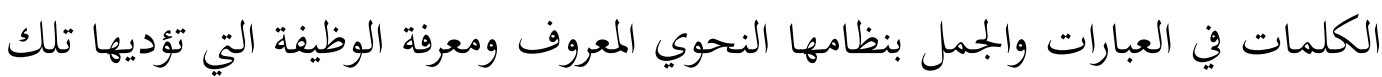
العلاقة والتي تدل عليها القرائن اللفظية والمعنوية بحسب العرف والوارد في اللغة يعيننا

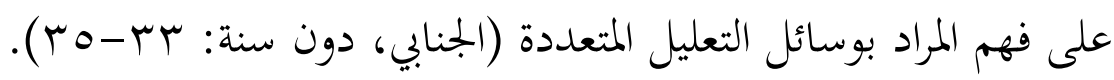

أدوات التعليل (الأحرف والأسماء)

لقد استعمل أسلوب التعليل في اللغة العربية الأدوات التي استعملتها العرب في

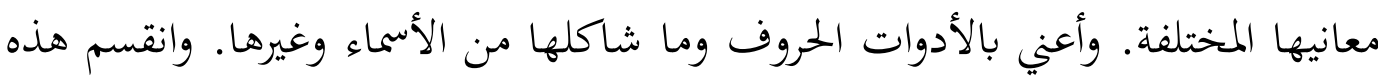

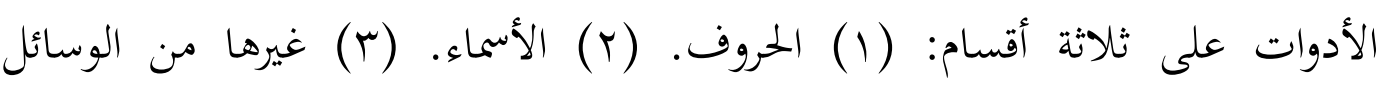

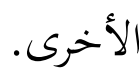

\section{التعليل بالحروف}

التعليل باللام: ومن معانيها التعليل. اللام هو أم باب التعليل والأصل فيه، وقد تختص اللام بين الحروف المفيدة للتعليل بأهما تستعمل فيه بكلا قسميه، التعليل بالغرض والتعليل بالسبب، إذ أن العلة المقترنة باللام قد تكون حاصلة قبل الفعل وقد تكون مرادا تحصيلها.

لقد ذكر أحمد خضير عباس في كتابه (أسلوب التعليل في اللغة العربية) بأن للام

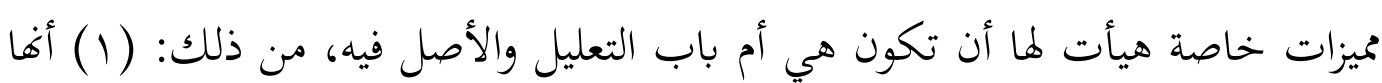
اختصت من بين الحروف المعللة الأخر بشيوع استعمالها في التعليل بكلا قسميه، التعليل بالغرض والتعليل بالسبب. (ب)كوها تدخل على الاسم الصريح والفعل المضارع، ومع

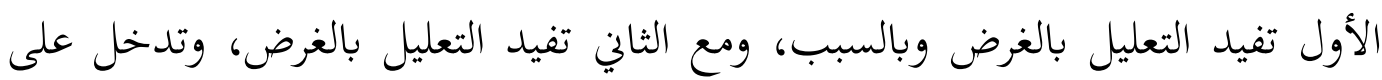


الحرف كذلك. (r) أها تأتي ظاهرة مرة، وقد تكون مقدرة مضمرة مرة أخرى. (ع) تستعمل في التعليل الحقيقي والتعليل المجازي. (0) يضاف إلى أنه يسأل بها في قسمي مرهي التعليل كليهما.

وأيضا قد أشار غير واحد من العلماء إلى أن اللام هي الأصل في التعليل، قال

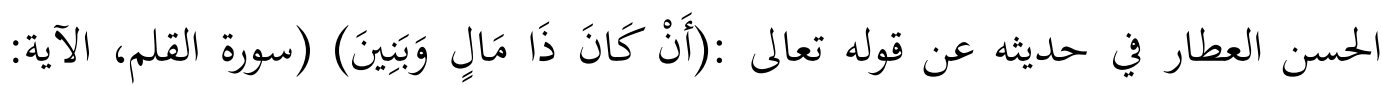
ع 1) جعل المقدر اللام دون باء السببية لأهفا الأصل في التعليل. وأشار ابن يعيش إل إل مثله قال: وباللام يخبر عن كل ذلك-يعني أغراض الفاعلين- وكي وحتى في معناها

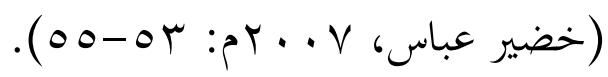

التعليل بالباء: لقد ذكر الحافظ جلال الدين عبد الرحمن السيوطي( ت: (1)

في كتابه "الإتقان في علوم القرآن" اثني عشر معنى للباء، ومنها: السببية، وهي التي

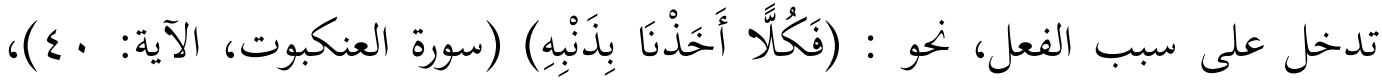

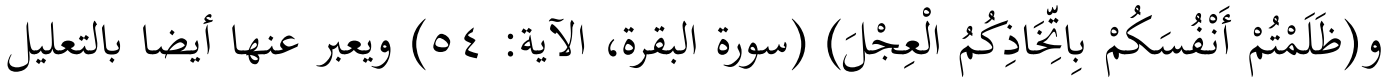

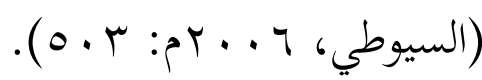
التعليل بالفاء: لقد ترد الفاء على أربعة أوجه: عاطفة، وجوابية، وللربط والسببية، وزائدة. ونخص بالبحث فضلا عن ذلك الفاء الداخل على الفعل المضارع المنصوب لأها سببية جوابية وهي عند البصريين عاطفة. والفاء تتضمن معنى التعليل عن طريق السبب في أغلب تلك الأوجه. التعليل بد(كي): وهي نصٌٌ في الدلالة على العلة والغرض، وتحمل الأحرف الأخرى عليها، فيقال : لام (كي)، وحتى بمعنى كي، ونحوهما. وهي وإن كانت حرفا واحدا، فقد نُزّلت منزلة حرفين، فتارة تكون حرف جر يفيد التعليل، وتارة حرفا مصدريا بمنزلة (أن).

التعليل بـ(حتى): (حتى) حرف لانتهاء الغاية، ويقع بعدها المضارع المنصوب بأن

المقدرة، ويكونان في تأويل مصدر مخفوض، وعندئذ لها ثلاثة معان منها: مرادفة (كي)

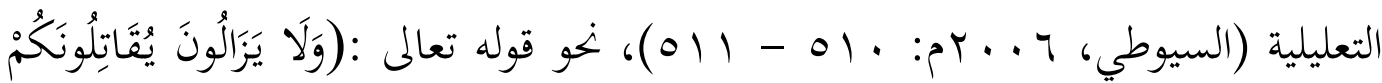




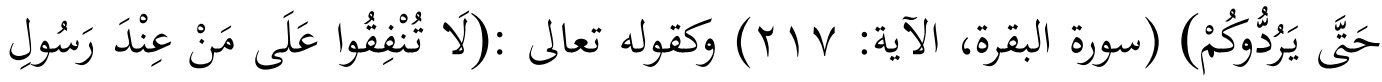

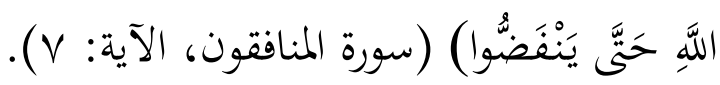

التعليل ب(من): وهو حرف من حروف الجر التي له معان كثيرة، وقد تفيد

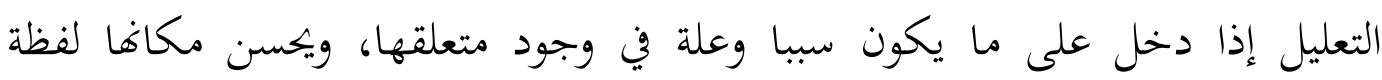

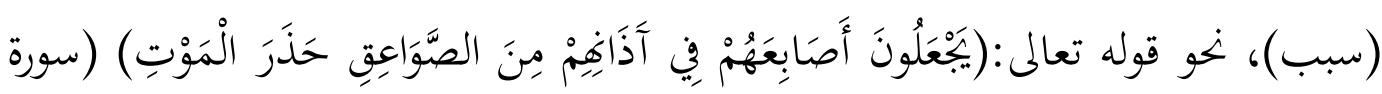

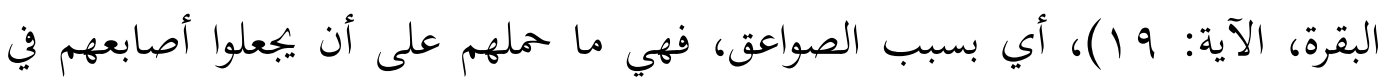

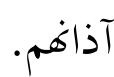

التعليل ب(عن): قد وردت (عن) حرف جر بستة معان، ومنها معنى التعليل،

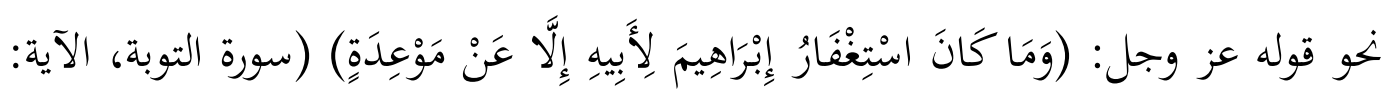

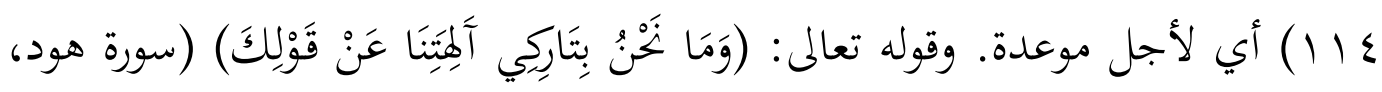

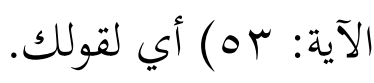

التعليل ب(في): كان (في) حرف جر يأني لمعان كثيرة، والأصل فيه الوعاء

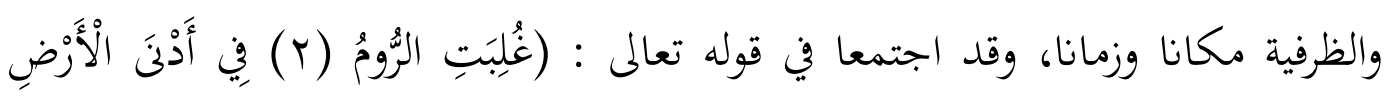

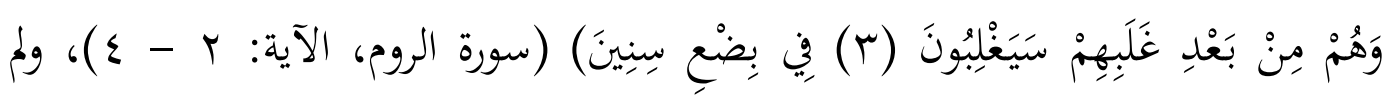
يثبت البصريون له غير هذا المعنى.

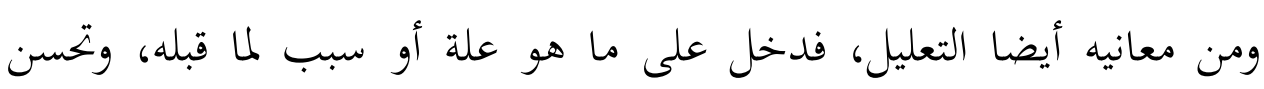

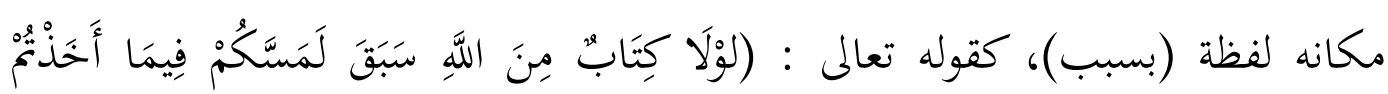

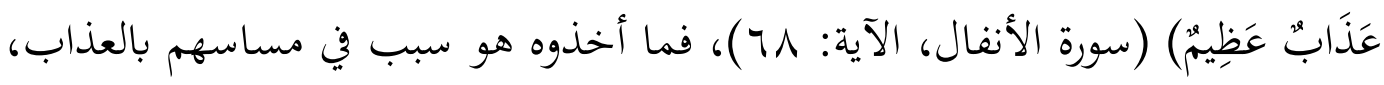

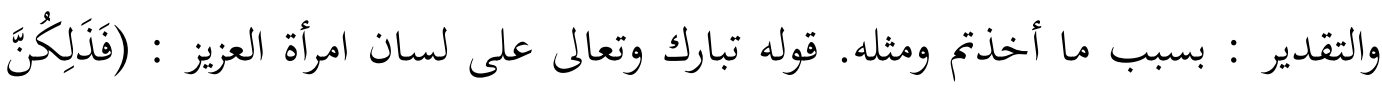

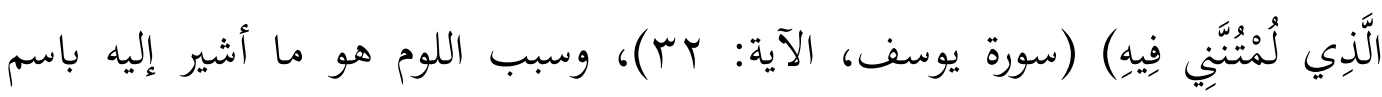
الإشارة وقد دخلت (في) على ضمر عائد عليه.

التعليل ب(الكاف): نصّ أكثر النحاة على إفادة الكاف معنى التعليل، كقوله

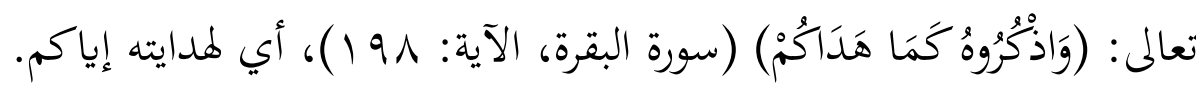


وقيّد بعض النحاة هذه الإفادة بأن تكون الكاف مكفوفة بـ(ما) الزائدة. وأجاز ابن هشام ججيئها للتعليل دون قيد الاقتران ب(ما)، فمما جار ججردا نو قوله تعالى :

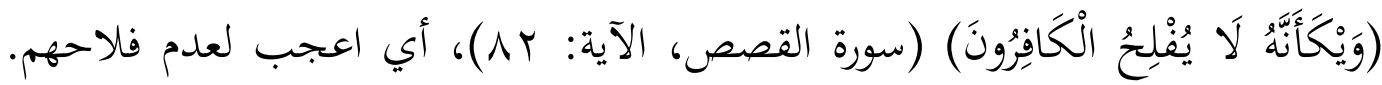

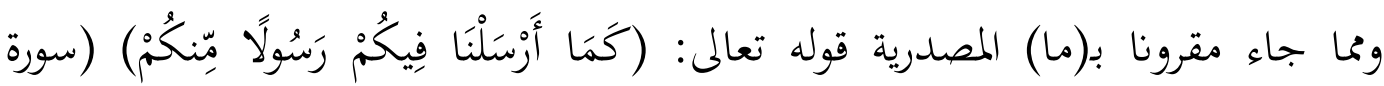

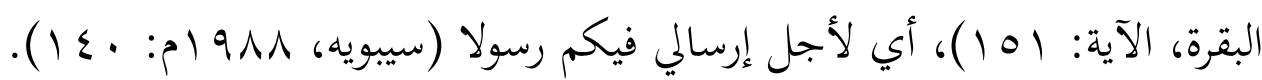
التعليل بد(إن): ذكر عبد القاهل الجرجاني أن (إن) قد تأتي للتعليل في موضع

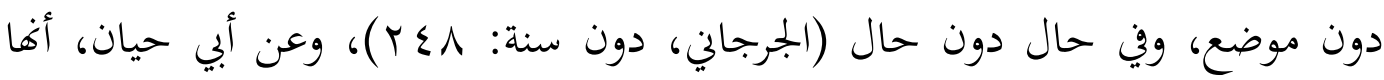

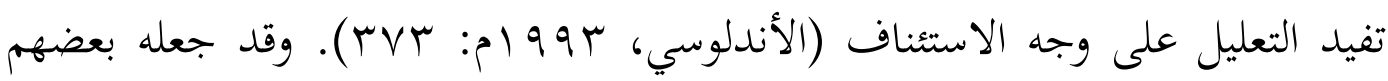

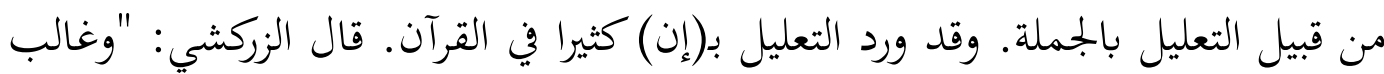

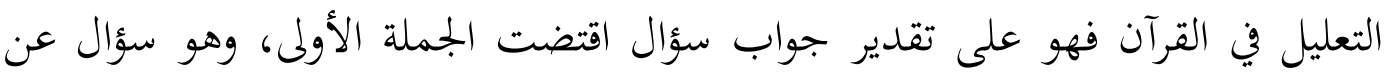

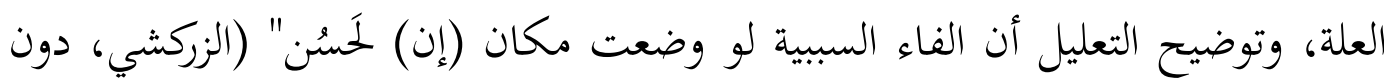
سنة: (97).

التعليل ب(على): حرف من حروف الجر التي يجر الظاهر والمضمر، وهو المشهور من مذهب البصريين. وذكر لها معان كثيرة منها معنى التعليل إذ إفا تأتي لإفادة التعليل إذا كانت داخلة على ما هو سبب في وجود متعلقها، كقولك: حمدت الله على عافيته، وكافأت المجد على فوزه، فإن العافية سبب الحمد، وفوز المجد سبب مكانب فافأته، وشبهي

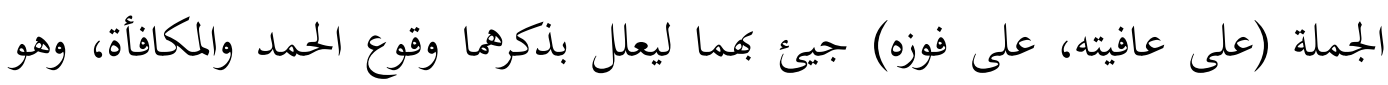
تعليل بالسبب، وذلك لأن ما دخلت عليه (على) سابق لما قبلها في الشعور والواقع. التعليل بج(إذ): ذكر صاحب البرهان أربعة الأوجه التي ترد بها (إذ)، ومنها

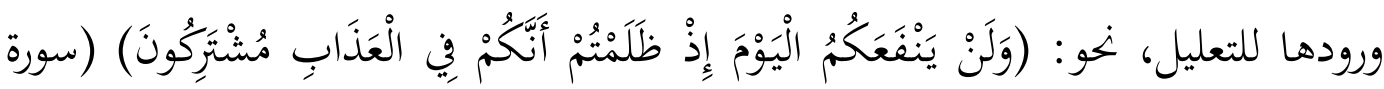

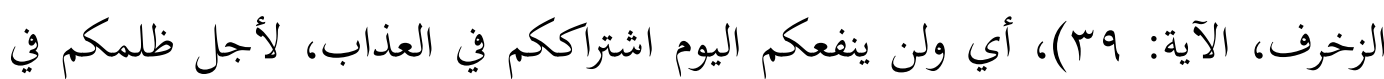
الدنيا.

هذه جملة من الأدوات التي تفيد التعليل في العربية بعد استقراء يكاد يكون شاملا. وسيتلو هذا الحديثَ حديثُ عن أدوات التعليل في سورة البقرة. 


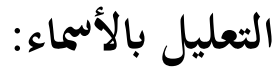

وأُسُّ الباب فيها المفعول له أو لأجله: اصطلح النحاة على تسمية المصدر الذي يبين التعليل أو السببية: "المفعول لأجله، أو له"، فقد عقد سيبويه له بابا بعنوان: "هذا لهابها

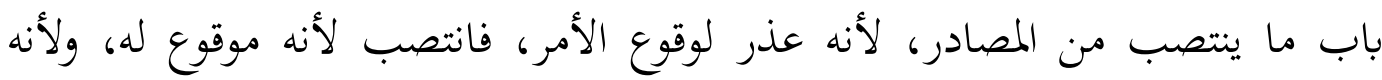

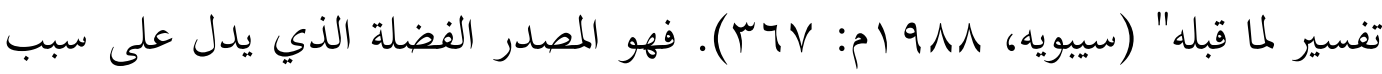
ما قبله، أي بيان علة ما قبله، فهو يأتي لأجل شيء آخر، بسببه حصل هذا المفعول،

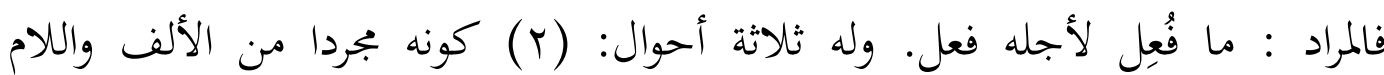
والإضافة. (r) كونه محلى بالألف واللام. (r) كونه مضافا. و يأتي منصوبا عندما توفرت له الشروط وهي:

أولا: أن يكون مصدرا. وهو على ضربين : مصدر صريح: نحو قوله تعالى :

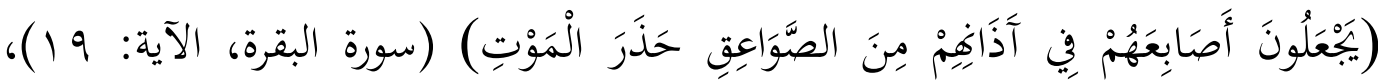

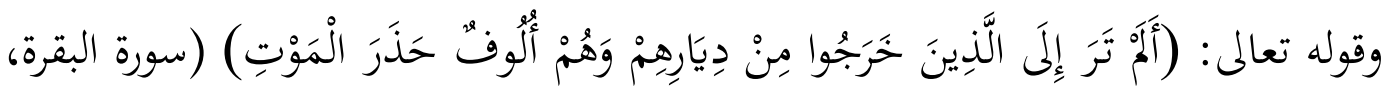

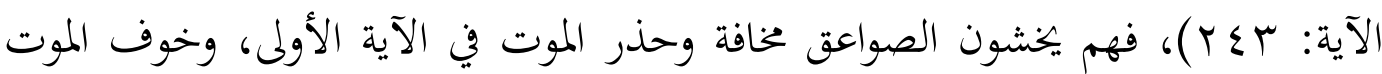
حذرا منه عند خروجهم من ديارهم وهم ألوف واصفا حالهم متعجبا من هذه الحال في الآية الثانية، فـ(حذر) في الآيتين مفعول لأجله وهو هنا علة وغاية معا. ومقدر بالمصندر:

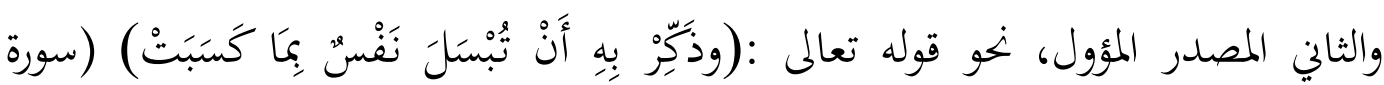

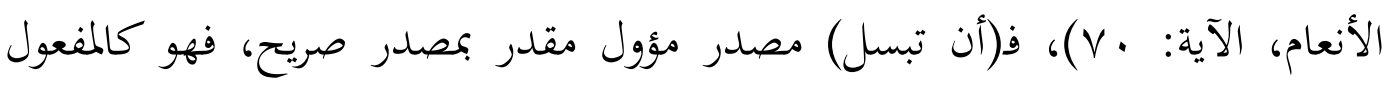
لأجله فيتعين تقدير لا النافية بعد لام التعليل المحذوفة، والتقدير : لئلا تبسل. ثانيا: أن يكون مفهما للعلة. بمعنى أن يكون مذكورا للتعليل فهو علة لأنه الباعث على إحداث الفعل والحامل عليه، كقولك : ضربته تقويما له، فإنه يستقيم أن لهن

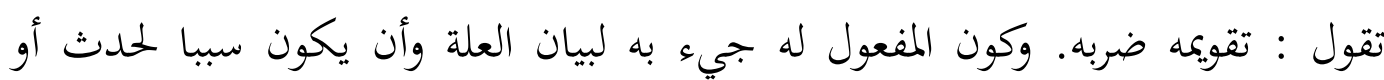

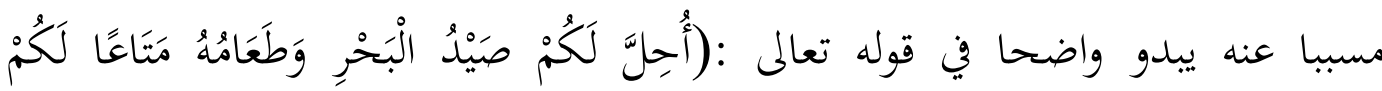

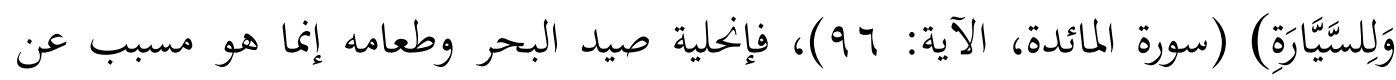

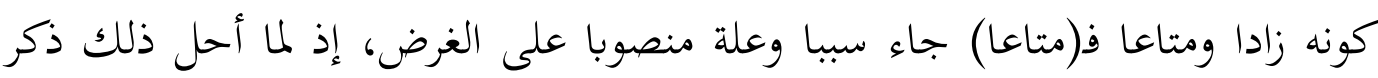

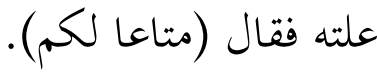


ثالثا: أن يتحد مع ما هو علة في الزمان. بأن يكون وقت الفعل المعلل والمصدر

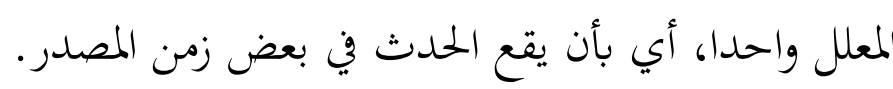

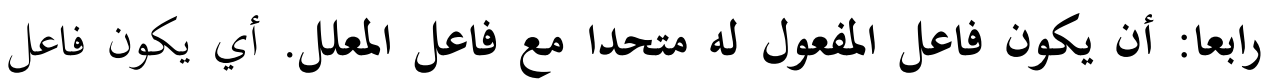
الحدث والمصدر واحدا، وذلك ليتحرز به عما إذا كان فعلا لغيره، فلا معنى لنصب (إكرامك) في نحو: جئتك لإكرامك الزائرين، لأن الفعل (جئتك) يقتضيه، فيكون بجراه مجرى المصدر الكائن من لفظه نهو: ضربت ضربة، فلا يتصور إكرام المخاطب الزائرين بالميء إليه إلا أن المشاركة في الفاعل ليست ضرورية.

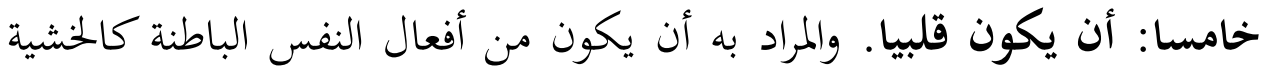
والرجاء والحب والبغض، وليس من أفعال الحواس الظاهرة كالقتل والقراءة، لأن العلة هي الحاملة على إيجاد الحامل على الشيء المتقدم عليه، وأفعال الجوارح ليست كذلك ولك فهي

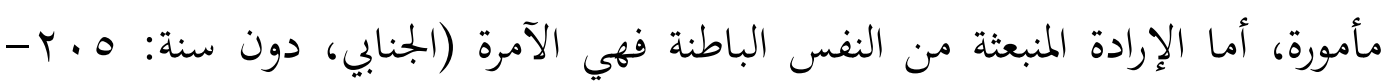
. (r.

\section{أسلوب التعليل في الثلث الأول من القرآن الكريم}

بعد ما تم بيان أسلوب التعليل-نظريا- من حيث اللغة والاصطلاح ثم يبحث الباحث -بإذن الله- في استعمال أسلوب التعليل -تطبيقا- في سورة البقرة مع توضيح معانيها عند المفسرين، وذلك بشكل جدولي. الجدول اـ بعض مواضع أساليب التعليل في سورة البقرة

\begin{tabular}{|c|c|c|c|c|}
\hline 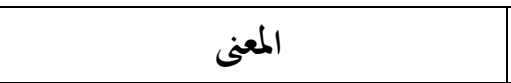 & 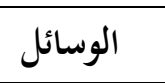 & الآية & 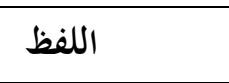 & 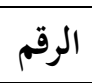 \\
\hline كذَكم وتكذيبهم العنداب الأليم لمؤلاء سببها & باء سبيية & 1. & بِمَاَ كَانُوا يَكْذِدُبُونَ & .1 \\
\hline يمدهم بطول العمر حتى يزيدوا في & في سبية & 10 & 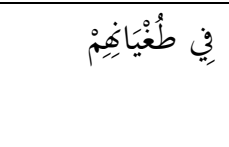 & .4 \\
\hline 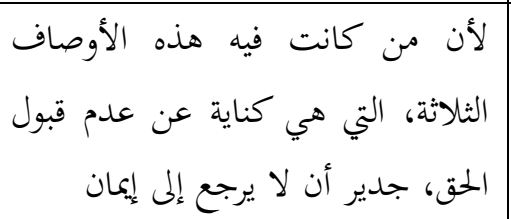 & فاء سبية & 11 & فَهُهم لَا يَرْحِعُونَ &.$r$ \\
\hline يجذرون حذر الموت & مفعول له & 19 & حَذَرَ الْمَّتِ & $\varepsilon$ \\
\hline
\end{tabular}




\begin{tabular}{|c|c|c|c|c|}
\hline أضاء من أجلهم & لام التعليل & $r$. & أَضَاءَ لَمُ & .0 \\
\hline اعبدوا الله كي تتقوه & لعل & YI & لَعَلََكُكْمْ تَتَّقُونَ & .7 \\
\hline لأجلكم & لام تعليلية & Tr & جَعَلَ لَكُمُمُ &.$V$ \\
\hline من الذي نزلنا & 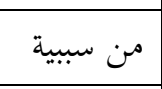 & r & 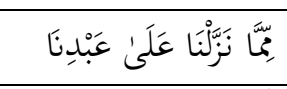 &.$\wedge$ \\
\hline هيئت من أجلهم & لام تعليلية & $r \varepsilon$ & أُعِدَّتْ لِلْكَافِرِينَ & .9 \\
\hline ودينكم لأجلكم ولانتفاعكم به في دنياكم & ل الام سبية & rq & خَلَقَ لَكُمْ & .1 . \\
\hline لأجلك ل & لام التعليل & $r$. & وَنْعَدِّسُ لَكَك & .11 \\
\hline لأجل آدم & ل ل ام سبية & $r \varepsilon$ & اسنجُجُدُوا لآَدَمَ & .14 \\
\hline لأن كوفما ظالمين مسبَّبُ عن القرب & فاء سبية & ro & فَتَكُونًَا & $.1 r$ \\
\hline حملهما على الزلة بسببها & عن سبية & 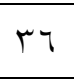 & 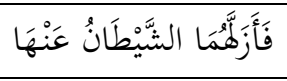 & $.1 \leqslant$ \\
\hline فبسبب التلقي من ربه تاب عليه & باء سبية & rv & فَتَّابَ عَلَئهِ & .10 \\
\hline فرقناه بسببكم وبسبب إنجائكم & باء سبية & o. & فَرَقْنًَا بِكُمُ الْبَحْرَ & .17 \\
\hline أي لكي تشكروا & لعل & or & لَعَلَّكُمْم تَشْكُرُورنَ & $.1 \mathrm{~V}$ \\
\hline أي لكي تتدوا & ل & or & لَعَلَّكُمْم تَهْتَدُونَ & .11 \\
\hline فنعلتم فتاب عليكم & فاء سبية & $0 \leqslant$ & فَتَابَ عَلَيْكُكْمْ & .19 \\
\hline لن نؤمن لأجل قولك بالتوراة & ل ام التعليل & 00 & لَن نُُْْْهِنَ كَكَك &.$T$. \\
\hline أي لكي تشكرو & لعل & 07 & لَعَلَّكُمْ تَشْكُرُورونَ & .41 \\
\hline سبن إنبديل سببه الظلم، وإن إنزال الرجز & فاء سببية & 09 & فَأَنْزَلْنَا & . Tr \\
\hline فضرب فانفجرت أي فانفجرت بسبب & فاء سببية & 7. & فَانْفَجَرَتْ & $.4 T$ \\
\hline لأجلنا & ل الام التعليل & 71 & يُ يُخْجِجْ لَنَا &.$T \varepsilon$ \\
\hline بسبب معصيتهم & باء سبيية & 71 & بِمَا عَصَوا & ro \\
\hline لكي تهتدوا & لعل & Tr & لَعَلَّكُمْ تَتَقُونُونَ & .47 \\
\hline من أجلهم & ل ام ل التعليل & 77 & 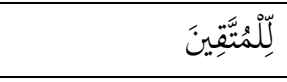 & $.4 V$ \\
\hline 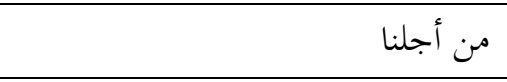 & ل ام ل ام التعليل & $\uparrow$ & ادْعُ لَنَا &. $\mathrm{.} \wedge$ \\
\hline من أجلنا & ل الام التعليل & 79 & الُْعُ لَنَا & .49 \\
\hline 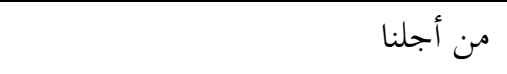 & لام التعليل & $v \cdot$ & ادْعُ لَنَا &.$r$. \\
\hline من أجلنا & ل ام التعليل & v. & يُبَبِينّ لَنَا &.$\mu$ \\
\hline
\end{tabular}




\begin{tabular}{|c|c|c|c|c|}
\hline كي تعقلوا & كي تعليلية & $\mathrm{Vr}$ & لَعَلَّكُمْ تَعْقِلُونَ & .rt \\
\hline الخشية سبب لهبوط الحجارة & من تعليلية & $V \varepsilon$ & مِنْ خَشْيَةِ اللَّهِ & r \\
\hline أن يؤمنوا لأجل دعوتكم لمم & لام التعليل & Vo & أَأنْ يُؤْمِنُوا لَكُمْ &.$r \varepsilon$ \\
\hline لكي يحاجوكم & 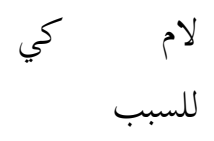 & VY & لِيُحَاجُوُْمْمْ & ס r. \\
\hline هي كسابقتها، وقد سبق الكلام عليها & من سبية & vq & رِمَّا يَكْسِبُونَ & דיץ. \\
\hline بسبب حديثكم لهم أو تحديثكم إياهم & باء سبية & VT & 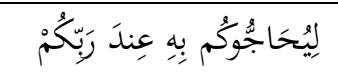 &.$r v$ \\
\hline لكي يشتروا به ثمنا & لام كي & vq & لِيَتْنَتَرُوا بِِِِ &.$r \wedge$ \\
\hline بسبب كسبكم & ما تعليلية & vq & مِمَّا يَكْسِبُونَ & .49 \\
\hline 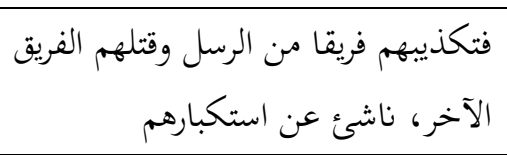 & فاء سببية & $\wedge \vee$ & 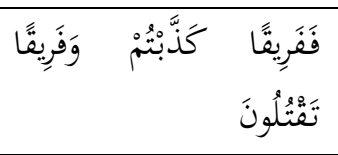 &.$\varepsilon$. \\
\hline فهم ملعونون بسبب ما تقدّم من كفرهم & باء سبية & $\wedge \wedge$ & بـكُفْرِهِمْ & \&1 \\
\hline متعلقب نزبل بالفعل & باء سببية & 19 & كَفَرُوا بِِِ &.$\varepsilon r$ \\
\hline كفرهم لأجل البغي & مفعول له & 9. & بَغْيًَا &.$\varepsilon r$ \\
\hline بسبب ما أنزل الله & باء سبية & 91 & آرِنْوا بِعَا أَنَزَلَ اللَّهُ &.$\varepsilon \varepsilon$ \\
\hline بسبب إقامة البينات & باء سبية & 94 & بِالْبَبِيَنَاتِ & . 20 \\
\hline كفرهم السابق لمم على عبادة العجل هو & باء سببية & 94 & بكِفْْرِهِمْ &.$\leqslant 7$ \\
\hline بسبب ما قدمته أيديهم & باء سبية & 90 & بِمَا قَدََّمَتْ أَيْدِيِِِهْ &.$\varepsilon V$ \\
\hline بسبب إذن الله له بتنزيله إياه عليك & باء سبية & $9 \vee$ & 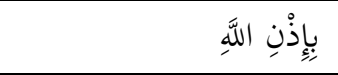 &.$\varepsilon \wedge$ \\
\hline بسبه & باء سبية & $1 \cdot r$ & وَمَا هُم بِضَارِِّينَ بِِِ &.$\leqslant 9$ \\
\hline وتي يكون الرد من تلقائهم وبإغوائهم & من سبية & $1 \cdot 9$ & مِّنْ عِندِ أَنْفِسِهِم & .0 . \\
\hline 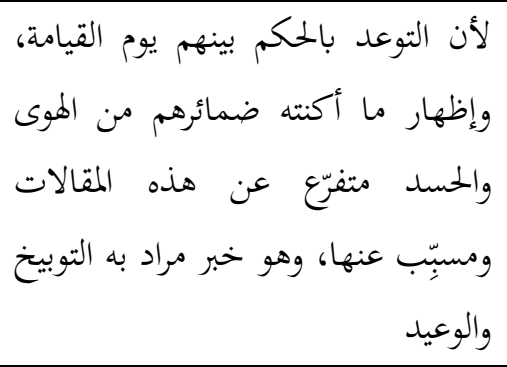 & فاء سببية & $11 r$ & 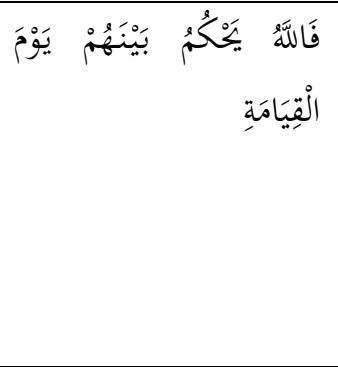 & .01 \\
\hline منعها كراهية أن يذكر فيها اسمه & مفعول له & $11 \leq$ & أَنْ يُذْكَرَ & .04 \\
\hline من أجل أو لأجل قوم يوقنون & ل الام تعليل & 111 & لَفَوْْرٍ يُوِقِنُونَ & $.0 \%$ \\
\hline
\end{tabular}




\begin{tabular}{|c|c|c|c|c|}
\hline بسبب إقامة الحق & باء سببية & 119 & 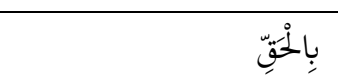 & $.0 \leqslant$ \\
\hline 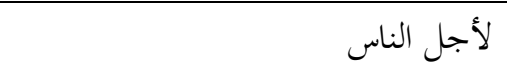 & لام التعليل & $1 T \varepsilon$ & إِيّ جَاعِلُكَ لِلنَّاسِ إِمَامًا & .00 \\
\hline من أجلهم & لام التعليل & lro & 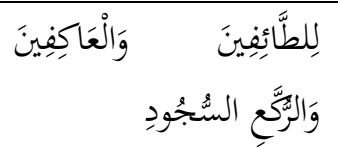 & .07 \\
\hline لأنك أنت السميع العليم & إن تعليلية & ITV & إِنَّكَ أَنتََ السَّمِيعُ الْعَلِيُ & $.0 \mathrm{~V}$ \\
\hline مثلها & لام التعليل & lrA & 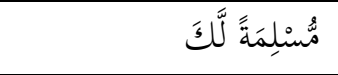 & .01 \\
\hline أسلِمْ لربّك & لام التعليل & $1 \pi 1$ & إِذْ قَالَ لَهُ رَبَّهُ أَسِْْمْ & .09 \\
\hline الأستلصه لكم، وتخيَّه لكم صفوة & لام التعليل & Irt & 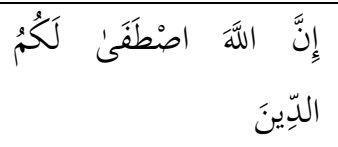 & .7. \\
\hline لأجل إرسال هؤلاء الرسل جميعا & لام التعليل & Tr & وَنَخْنُ لَهُ مُسنْلمُونَ & .71 \\
\hline للتعقيب مع التسبب & فاء سبية & 1ro & فَاحْذَرُوهُ & T4 \\
\hline من أجلكم & ل الع العلة & IrV & 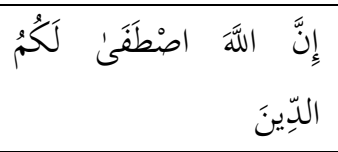 & זיד. \\
\hline لأجله كانت عبادتنا & ل ام ل التعليل & 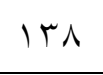 & وَتَنَنُْ لَهُ عَابِدُونَ & $.7 \varepsilon$ \\
\hline لكي نعلم & لام كي & $1 \leqslant r$ & لَنَعَعَمَ & .70 \\
\hline & إن تعليلية & $1 \leqslant r$ & 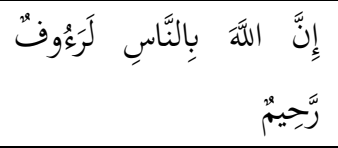 & .77 \\
\hline لكي تَتدوا إلى قبلة أبيكم إبراهيم & لعل & 10. & وَرَعَلَكَكُمْ تَهْتَدُونَ &.$T V$ \\
\hline 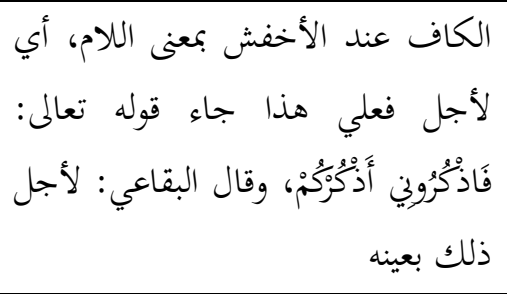 & كاف التعليل & 101 & كَمَا أَرْنَلْنَا &.$\uparrow \Lambda$ \\
\hline والحنع الناس في تجارقم وأسفارهم للغزو & باء السببية & 17 & بِمَا يَنَفعُ النَّاسَ & .79 \\
\hline بسبب الماء & باء السبية & $17 \varepsilon$ & فَأَحَيَا بِِِ الْأَرَْْ &.$v \cdot$ \\
\hline وتقطعت بسبب كفرهم & باء السببية & 177 & 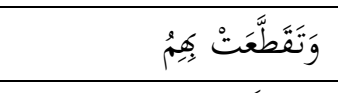 & .81 \\
\hline ليت لنا كرة فنتبرأ & فاء السببية & 178 & 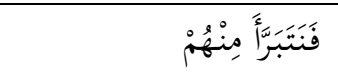 &.$V T$ \\
\hline 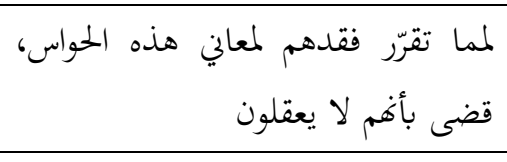 & فاء السببية & $|v|$ & فَهُهْ لَا يَعْعِلُونَ &.$v r$ \\
\hline من أجل غير الله من الأنصاب والأوثان & لام التعليل & IVT & 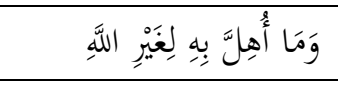 &.$v \varepsilon$ \\
\hline
\end{tabular}




\begin{tabular}{|c|c|c|c|c|}
\hline وما إليهما & & & & \\
\hline ذلك العذاب حاصل لهم بكتمان ما & باء السببية & $1 V 7$ & 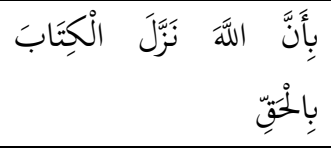 & . Vo \\
\hline اختلفوا بسببه & في السببية & $1 V 7$ & رِي الْكِتَابِ &.$\vee 7$ \\
\hline 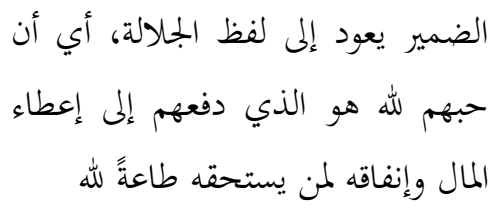 & على التعليلية & IVV & عَلَى حُبِّهِ &.$V V$ \\
\hline أنكم أيها المؤمنون وجب عليكم القتل & في السببية & $I \vee \wedge$ & رِي الْقَتْلَى &.$\vee \wedge$ \\
\hline الأنقتله العبد مقتول بقتله الحر، والعبد مقتول & باء السبية & $1 \vee \wedge$ & 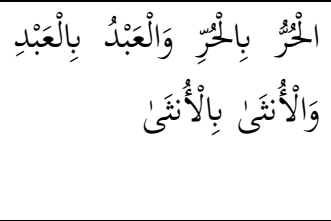 &.$\vee 9$ \\
\hline لكي تتقوا & لعل & 189 & لَعَلَّكُمْ تَتَقُقُونَ &.$\Lambda$. \\
\hline 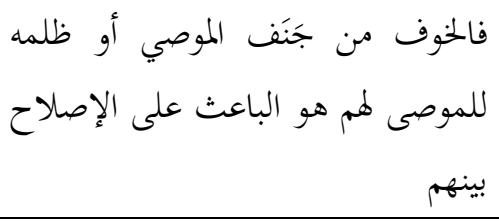 & فاء السببية & 111 & فَأَصْلَحَ بَيْهَهُمْ & .11 \\
\hline لتتقوا & لعل & $1 \wedge r$ & لَعَلََكُمْمْ تَتَقُقُونَ &.$\lambda r$ \\
\hline لأجله & لام التعليل & $1 \wedge \varepsilon$ & فَهُوَ خَيْرِ لََّهُ &.$\wedge r$ \\
\hline من أجلكم & ل الام التعليل & $1 \wedge \varepsilon$ & أَنْ تَصُومُوا خَيْرِ لَّكُمْ &.$\wedge \varepsilon$ \\
\hline لتعلموا ما تعملون ولتكملوا العدة & لام التعليل & 110 & رلِتُكَمِلُوا & .10 \\
\hline علة ما علمتم من كيفية القضاء والخروج & لام التعليل & 110 & 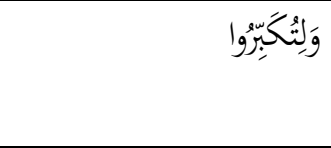 &.$\wedge 7$ \\
\hline لهدايته إياكم & على تعليلية & 110 & عَلَى مَا هَدَاكُمْ &.$\wedge \mathrm{V}$ \\
\hline علة الترخص والتسهيل & لعل & 110 & وَلَعَلَّكُمْ تَشَكْرُوُونَ &.$\wedge \wedge$ \\
\hline فإلإيمان بالله مسبب عنه رشادهم، أو & لعل & 117 & لَعَلََّهُمْ يَرْشُدُونَ & .19 \\
\hline من أجلكم، من أجلهن & لام التعليل & $1 \wedge \mathrm{V}$ & 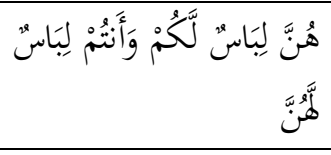 & .9 . \\
\hline فبسبب ذلك لا تقربوها & فاء السببية & $1 \wedge \mathrm{V}$ & فَلَا تَقَرَبُوهَا & .91 \\
\hline بسبب فعل الباطل & باء السببية & $1 \wedge 1$ & بِالْبَاطِلِ & .94 \\
\hline
\end{tabular}




\begin{tabular}{|c|c|c|c|c|}
\hline لكي تفلحوا & لعل & 119 & لَعَلَّكُمْ تُنْلِحُحُونَ & .94 \\
\hline لأجل نصرة سبيل الله & في سبية & 19. & فِي سَبِيلِ اللَِِّ & $.9 \leq$ \\
\hline أجله. & ل ام المفعول له & 194 & لِّلِّ & .90 \\
\hline كي لا تكون & حتى تعليلية & 194 & حَتَّى لَا تَكُونَ فِتْنَةُ & .97 \\
\hline هي كسالفتها & في تعليلية & 190 & أَنْفِقوا فِي سَبِيلِل اللَِِّ & $.9 V$ \\
\hline لأجل الله & لام العلة & $19 \varepsilon$ & 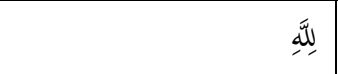 & .91 \\
\hline وتزوّدوا التقوى أي من التقوى & فاء سببية & $19 \mathrm{~V}$ & فَإِنَّ خَيْرَ الزَّادِ التَّقْوَنُ & .99 \\
\hline اذكروه لأجل هدايته إياكم & كاف تعليلية & 191 & كَمَا هَدَاكُمْ & $.1 \ldots$ \\
\hline إن الإفساد مقصود لهذا الساعي & ل ل ام التعليل & $r .0$ & لِيُفْسِدَ فيها & $.1 \cdot 1$ \\
\hline من أجل الإثم الذي في قلبه، يعني & باء سبية & $r \cdot T$ & 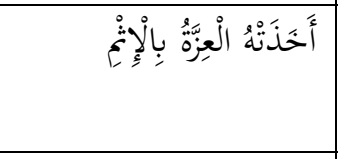 & $.1 \cdot r$ \\
\hline لأجل ابتغاء مرضات الله & مفعول له & $r \cdot v$ & ابتِغَغاءَ مَرْضَاةِ اللَِِّ & $.1 \cdot 4$ \\
\hline إن الشيطان عدو لأجلكم أو بسبكم & ل ل ام التعليل & $r \cdot \Lambda$ & 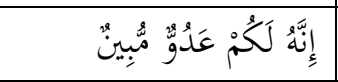 & $.1 \cdot \varepsilon$ \\
\hline من أجلهم زيَّن الشيطان الدنيا، فهم & ل الام التعليل & rIT & لِلَّذَينَ كَفَرُوا & .1 .0 \\
\hline كسابقتها & مفعول له & $r \mid r$ & بَغْغِاً & .1 .7 \\
\hline وزلزلواكي يقول الرسول & حتى تعليلية & $Y \backslash \varepsilon$ & حَتَّى يَقُولَ الرَّسُولُ & $.1 \cdot \mathrm{V}$ \\
\hline كي يردوكم عن دينكم & حتى تعليلية & TIV & 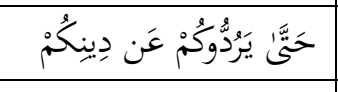 & $.1 \cdot 1$ \\
\hline تقدم الكلام عليها & في سبية & Y\ᄉ & وَجَاهَدُوا فِي سَبِيلِ اللَّهِ & .1 .9 \\
\hline لتنفكروا & لعل تعليلية & 519 & لَعَلَّكُمْ تَتَفَكَكَرُونَ & .11. \\
\hline لإجلهم & ل الام التعليل & rr. & 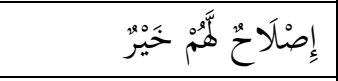 & .111 \\
\hline قد تقم معناها، فلا معنى للإعادة & لعل تعليلية & TrI & كَعَلَّهُمْ يَتَذَكَرَّرونَ & $.11 Y$ \\
\hline بسببه أو من أجله & في سبية & TrT & رِي الْمَحِيضِ & $.11 r$ \\
\hline لأجل أنفسكم أي لنفعها & لام العلة & TrT & 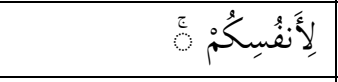 & $.11 \varepsilon$ \\
\hline كراهية أن تبروا & مفعول له & $r Y \leq$ & 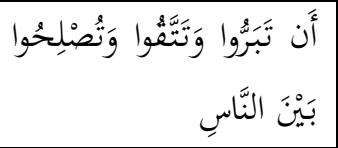 & .110 \\
\hline بكسب قلوبكم & باء سبية & r ro & بِمَا كَسَبَتْت قُلُوبُكُمْ & .117 \\
\hline يحلفون بسبب نسائهم & من سبية & TrT & 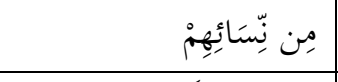 & $.11 \mathrm{~V}$ \\
\hline من أجل أنفسهن & باء سبية & rYN & 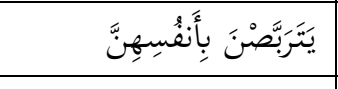 & .111 \\
\hline يمتد عدم التحليل له إلى أن تنكح زوجا & حتى تعليلية & $r r$. & حَتَّى تَنكِحَ زَوْجَا غَيْرَهُ & .119 \\
\hline
\end{tabular}




\begin{tabular}{|c|c|c|c|c|}
\hline غيره & & & & \\
\hline مضارين لتعتدوا & مفعول له & rt & ضِرَارًا & $.1 \%$. \\
\hline بسبب التراضي بينهما & عن سبية & Tra & عَنْ تَرَاضٍ &.$|r|$ \\
\hline كالباء في الآية السالفة & باء سبية & $r T \varepsilon$ & 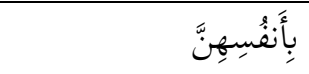 & $.1 T r$ \\
\hline كسالفتها & كاف تعليلية & 149 & كَمَا عَلَّمَكُكُم & $.1 \pi r$ \\
\hline لأجل ما فعلن & في سبية & $r \varepsilon$. & فِي مَا فَعَلْنَ فِي أَنْفُسِهِنَّ & $.1 T \leqslant$ \\
\hline لكي تعقلوا & لعل تعليلية & $r \leqslant r$ & لَعَلَّكُمْ تَعْقِلُونَ & .1 To \\
\hline حذرهم للموت يسببهم إلى الخروج من & مفعول له & $r \leqslant r$ & حَذَرَ الْمَوْتِ & $.1 Y 7$ \\
\hline سبق الكلام عليها & في سبية & $r \leqslant \varepsilon$ & فِي سَبِيلِ اللَّهِ & $.1 T V$ \\
\hline لأجله يضاعف الله له الاجر والمثوبة & اللام للعلة & $r \leqslant 0$ & فَيُضَاعِفَهُ لَهُ & $.1 Y \wedge$ \\
\hline ل الأجلنا & لام التعليل & $r \leqslant \tau$ & ابْعَثْ لَنَا & $.11 \% 9$ \\
\hline سبق الكلام عليها & في سبية & $r \leqslant \tau$ & فِي سَبِيلِ اللَِّّ & $.1 \%$. \\
\hline بسبب إذن الله & باء سبية & $r \leqslant q$ & ل & $.1 \pi$ \\
\hline سبق الكام عليها & باء سببية & rol & بإذن الله & Trt \\
\hline سبق الكام عليها & باء سببية & ror & بالحق & 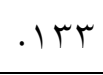 \\
\hline الباء للسببية وهي متعلقة بـ(يجيطون) & باء سببية & roo & بعِّا شَاءَ & $.1 T \varepsilon$ \\
\hline لأن آتاه & مفعول له & roN & أَنْ آََاهُهُ اللَّهُ & . \\
\hline للسببية والتعقيب & فاء سببية & roq & فَأَمَاتَهُ اللَّهُ مِائَة عَامِ & ד4 - (1) \\
\hline 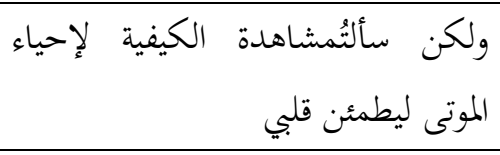 & لام - امي & ry. & لِيَطْمَيَنَّ & $.1 \mathrm{rV}$ \\
\hline سبق الكلام عليها & في سبية & rYI & في سَبِيلِ اللَّهِ & $.1 \% \wedge$ \\
\hline سبق الكام عليها & في سبية & rat & فِي سَبِيلِ اللَّهِ & $.11 \%$ \\
\hline ينفق مرائيا & مفعول له & rtra & رِعَاءَ النَّاسِ & $.1 \varepsilon$ \\
\hline \multirow{2}{*}{ للتعقيب والسبيية } & فاء سبيية & TYE & فَأَصَابَهُ وَابِلُْ & $.1 \leqslant 1$ \\
\hline & مفعول له & ryo & انبتْغَاءَ مَرْضَاةِ اللَّهِ & $.1 \leqslant r$ \\
\hline تقدم معناها & ل & rYT & لَعَلَّكُمْ تَتَفَكَُُوْونَ & $.1 \leqslant r$ \\
\hline من طيبات ما أخرجنا لكم من الأرض كسبتم، وأنفقوا & ل ام التعليل & rTV & كَكَمْ & $.1 \leqslant \varepsilon$ \\
\hline فالإخفاء خير من أجلكم & ل ل ام التعليل & rvi & خَيْرِ لََكُمْْم & $.1 \leqslant 0$ \\
\hline
\end{tabular}




\begin{tabular}{|c|c|c|c|c|}
\hline فهو لأنفسكم & لام التعليل & TVT & فَلَأَنْفُسُكُمْْم & $.1 \leqslant 7$ \\
\hline تعففهم & من سبية & $T V T$ & مِنَ التَّعَفُُّفبِ & $.1 \leqslant V$ \\
\hline ذلك القيام كائن بسبب أفم & باء سببية & rVo & ذلك بأفم قالوا & $.1 \leqslant 1$ \\
\hline اللام هنا كاللام هناك & ل الام التعليل & r人. & خَيْرِ لَّكُمْ & $.1 \leqslant 9$ \\
\hline من أجلها أي وأعون على إقامتها & ل الام التعليل & rAT & وَأَقْوَمُمُ لِلشَََّهَادةة & .10. \\
\hline بسببه & باء سبية & $r \wedge \varepsilon$ & 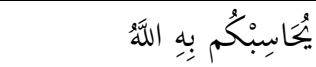 & .101 \\
\hline واللام هنا مردّدة بين البيان والعلة، & لام العلة & 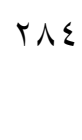 & فَيَغْغِرِر لِمَنْ يَشَاءُ & .104 \\
\hline وألأن كونه تعالى مولاهم ومالك تدبيرهم ينشأ عن ذلك النصرة لهم على & فاء سببية & 「人 & 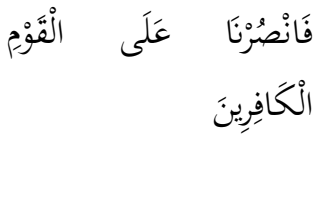 & .104 \\
\hline
\end{tabular}

بعد أن عرضنا لمواضع أسلوب التعليل في سورة البقرة بشكل جدولي، تستبين لنا

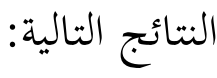

اتضح من الجدول أن (اللام) هي أم باب التعليل والأصل فيه. حيث أن لها مزايا خاصة بها جعلت منها أن تكون أم باب التعليل والأصل فيه. وذلك أنها الأكثر استعمالا حيث ورد هذه الأداة في سورة البقرة أكثر من به صورة في التعليل من بين الأساليب الأخرى المستعملة فيه، وأها يعلل بها في الاسم والفعل والحرف، فتفيد تعليلا بالغرض وبالسبب بحسب دلالة المعنى، وتأتي ظاهرة ومضمرة في التعليل الحقيقي والمجازي. وهي كغيرها من الحروف التي تكون الأصل في أبوابها، مثل الهمزة في الاستفهام والباء في الإلصاق وعن في الجماوزة، وغير ذلك من الأدوات المستعملة في مجال معانيها. ويتضح من الجدول أن (الباء) قد وردت في سورة البقرة أكثر من VT صورة حيث أها عند النحاة تدل على معنى السبب والتعليل. وأن تعلقها يؤثّر في معناها، وكذا معنى ججرورها، وعود الضمير (مخفوضها محلا) ومعنى تعلقها. وقد اتخدم النحاة المفسرون التعليل والسببية بمعنى. 
إن السببية معنيً لا يكاد يفارق الفاء عند عطفها جملة على جملة، صراحة أو ضمنا. صحيح، لا يلزم من عطف الجمل على بعضها بالفاء أن تكون الفاء للسببية، ولكن ذلك غالب عليها. ومما يؤثر في معنى الفاء وتوجيهه نحو السبية: معنى ما قبلها، والقراءة القرآنية، ومعنى العامل. ويشترط في الفاء الواقعة في جواب الطلب الدالة على

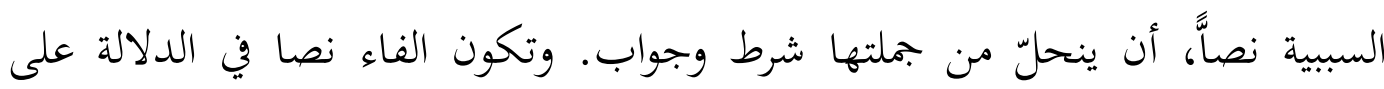

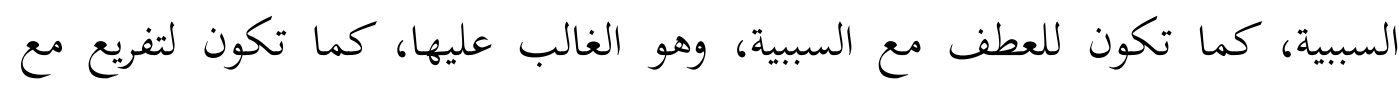
السببية. وهي جملة أحوالها مع هذا المعى. وقد وردت الفاء بمعنى السبب في سورة البقرة

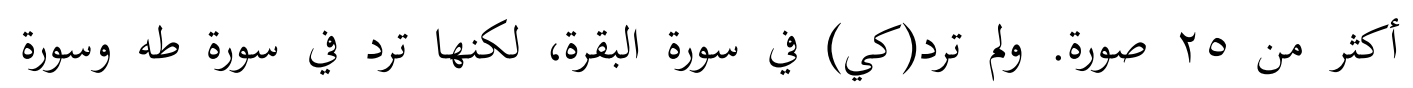
القصص.

من الجدول يظهر أن (حتى) تكون للتعليل بالجمل على (كي)، وهو أحد

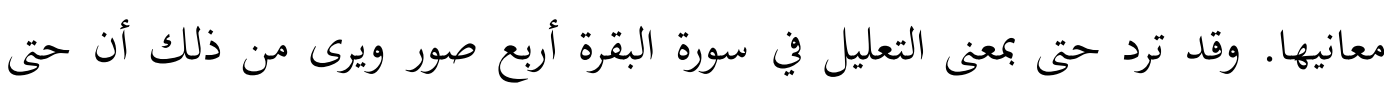

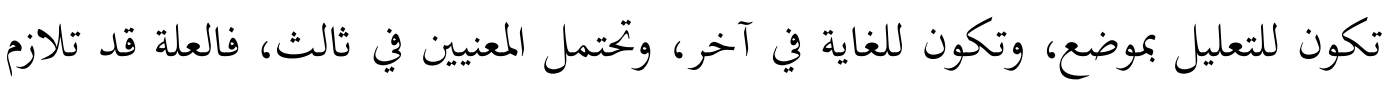
الغاية، والعكس.

ترد (مِن) للتعليل في سورة البقرة أكثر م صورة، كما تكون لغيره من المعاني، من

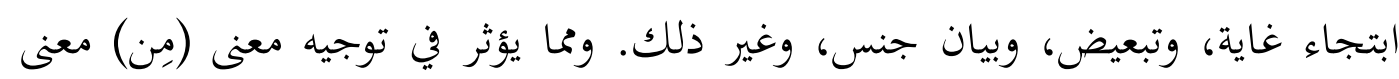

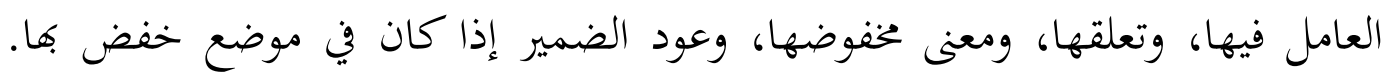

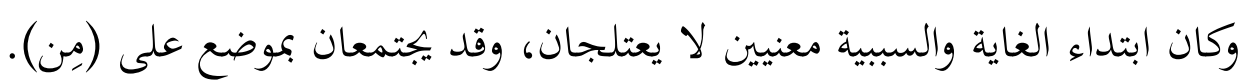

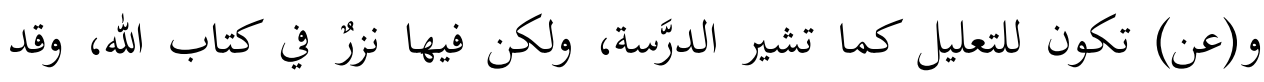

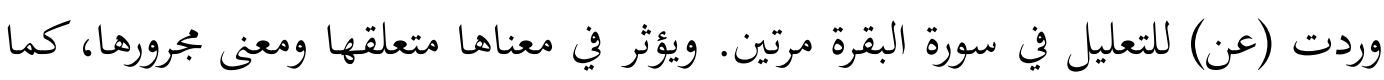
أن له تأثيرا في نظائرها من الأحرف الدالة على العلّة.

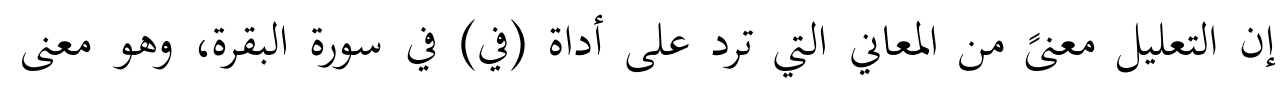
خفي على أكثر النحويين مع ورودها عليه في القرآن العزيز والحديث والشعر القديم كما

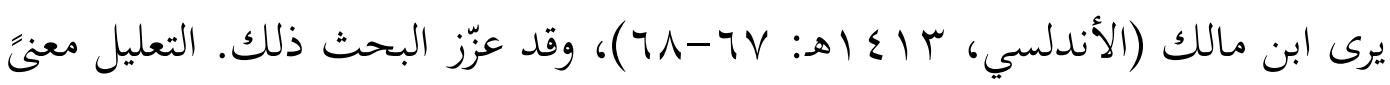

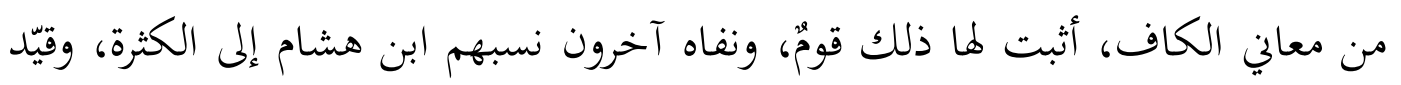

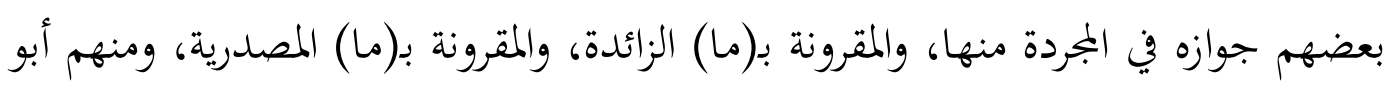


علي الفارسي. وترد في سورة البقرة أكثر من ه صورة، وقد أثبت شواهد القرآن دالة على

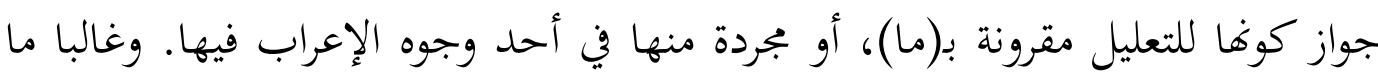
تكون متلوة باسم الإشارة في حال تجردها إلا في: (ويكأنه). ومما يؤثر في توجيه معناها : تعلقها، والوقف، وعود الضمير (مدخولما).

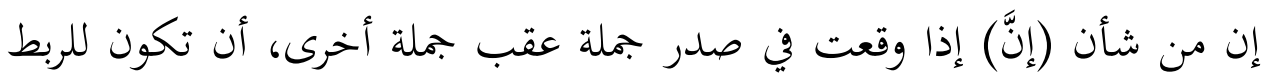
والتعليل، وتغني غناء فاء السبب، وجملتها حينئذ استئنافية مراد بها التعليل، وهي جملة مفصولة، وفصلها كلا فصلٍ، لغناء (إنّ) عن العاطف الفاء. التعليل بإن قد يكون تعليلا

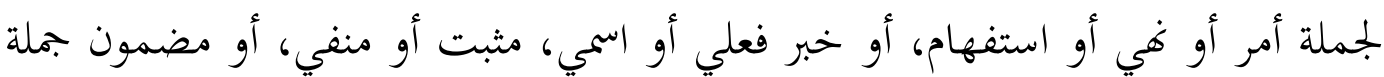

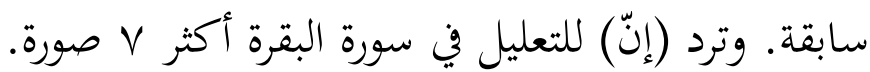

قد وجدت صورة واحدة لتعليلية (على) وهي آية: 11 ا من سورة البقرة. فعلى سلى الرغم من جواز كونا للتعليل فيها إلا أن دلالتها على الاستعلاء مجازا أو حقيقة لم تمنفك النك عنها في أحد أعاريبها. إنّ (إذ) التعليلية تكون حرفا مصدريا، وهو المختار، فهو مذهب حسن تؤيده شواهد الدراسة يجمع بين آراء القبليين من الذاهبين إلى ظرفيتها، ومنهم الشيخ عضيمة

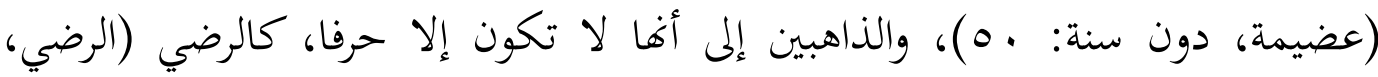
ب99 (1م: 1 • 1). لم أجد في هذه السورة صورة من إذ التعليلية. ومما يؤثر في إعراب المفعول له: معنى لفظه المعجمي والتركبي، والقراءة القرآنية، وأحكام الوقف. وينصب المفعول له مفعولا له آخر يكون علةً فيه، وترد المفعول له في سورة البقرة أكثر من 10 صورة.

الحخلاصة

ونستبط من نتائج هذا البحث أن أسلوب التعليل في سورة البقرة ينقسم إلى

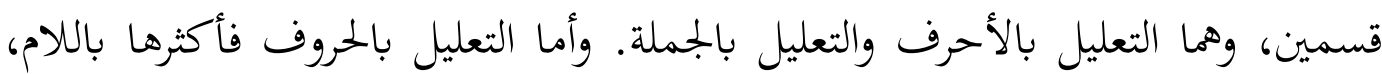

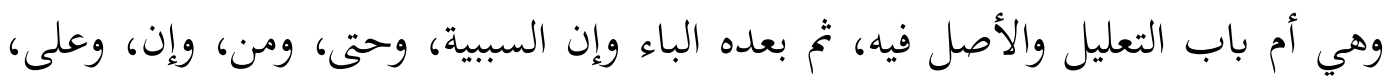

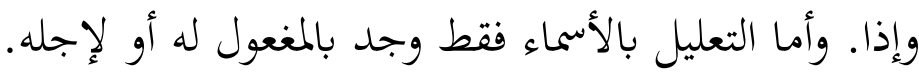


وفي غاية البحث بتوفيق الله ولطفه أقول لكم: فهذا ما هداني الله إليه، وما أعاني

عليه، فإن كنت قد أصبت فذلك فضل الله، وإن كانت الأخرى فحسبي أني بشرٌ أخطئ وأصيب، وأستعيذ بالله من الشيطان الرجيم. وآخر دعوانا أن الحمد لله بنعمته تتم الصالحات وبالله التوفيق. و واسنعيل.

\section{المراجع}

الجرجاني. دلائل الإعجاز. القاهرة: مكتبة الخانجي، دون السنة. الأندلسي، جمال الدين بن مالك. شواهد التوضيح والتصحيح لمشكاتلات الجامع

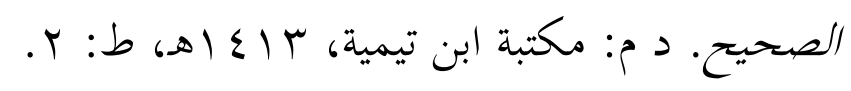

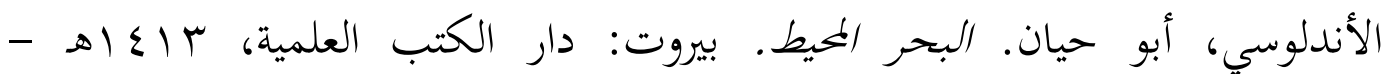
. 1994

الجنابي، يونس عبد مرزوك. أسلوب التعليل وطرائقه في القرآن الكريم-دراسة نحوية. ليبيا:

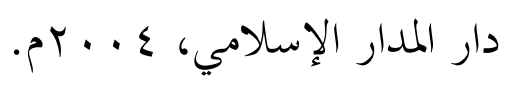

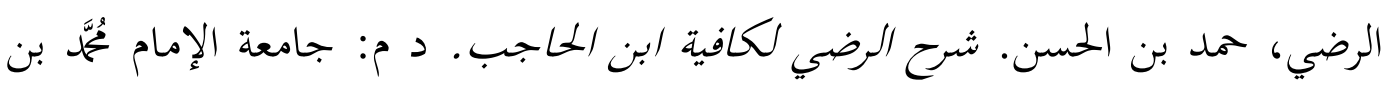

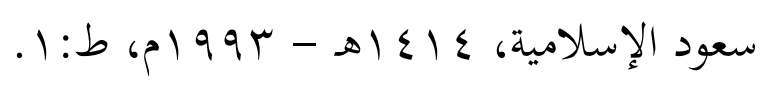

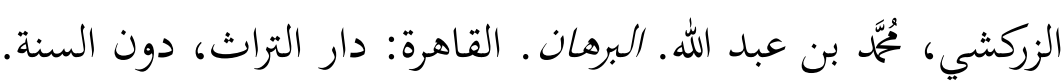

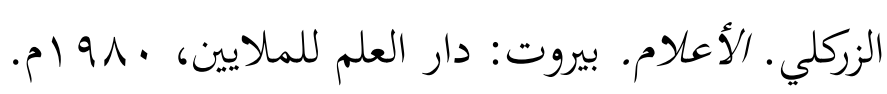

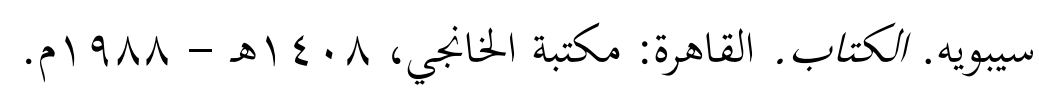

السيوطي، جلال الدين. الإتقان في علوم القرآن. بيروت: دار ابن كثير للطباعة والنشر مانيه

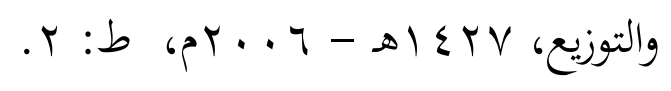

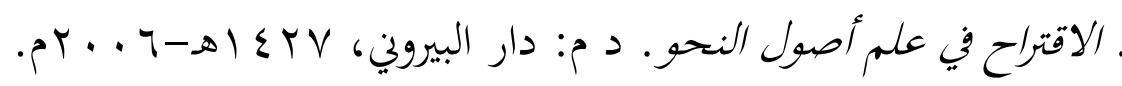

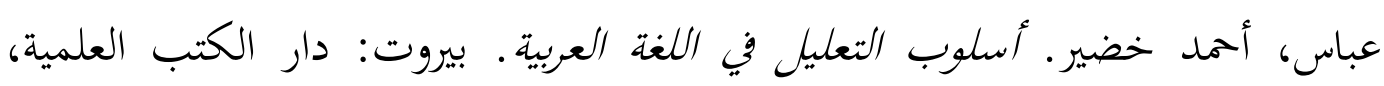

$$
\text { . } T \text { T.V V - D } \leqslant Y \Lambda
$$

عضيمة، يُحَّم عبد الخالق. دراسات لأسلوب القرآن الكريم. القاهرة: دار الحديث، دون 


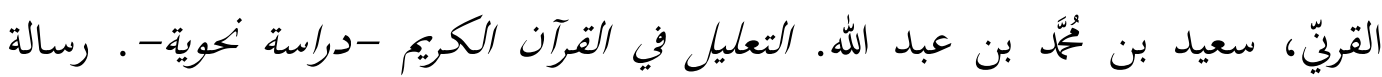

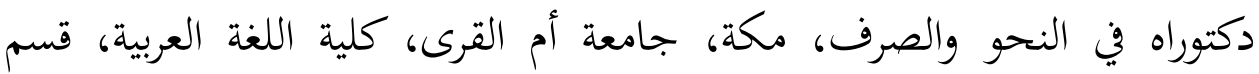

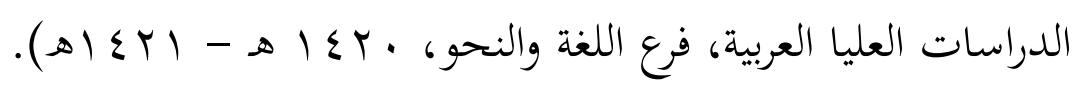

منظور، ابن. لسان العرب. القاهرة: دار المعارف، دون السنة.

هر، هادي. التعليل في اللغة العربية. بغداد: مجلة آداب المستنصرية، 9AV ام، العدد

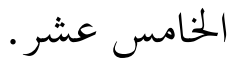

